Jakub Szymczak

Uniwersytet im. Adama Mickiewicza, Poznań

\title{
Kinematografia w Kurdystanie. Obraz Kurdów w filmach Bahmana Ghobadiego
}

Nie byłem $i$ wcią̇ nie jestem po prostu zakochany $w$ kinie, jestem pijany kinem, porwany przez nie, czuję przez nie ból, który sprawia, $\dot{z} e$ wydaje mi się, że jestem pijany, nie wiedzac, co robię ${ }^{1}$.

Bahman Ghobadi

Kinematografia, rodzaj sztuki audiowizualnej, jest w dziejach kultury stosunkowo młodą dziedziną działalności artystycznej. Jej ponadstuletnia historia obfituje jednak w różnorodne gatunki i formy wyrazu. Dociera ona praktycznie w każde miejsce na Ziemi. Kino może służyć jako źródło masowej rozrywki, kopalnia motywów, cytatów i wzorców postaw, które przedostają się do codziennego życia, może jednak także stać się medium pogłębionej artystycznej refleksji lub sposobem dokumentowania otaczającej nas rzeczywistości. W niektóre miejsca kino dotarło znacznie później niż do Europy uważanej za jego ojczyznę. Tak właśnie wygląda to $\mathrm{w}$ przypadku kinematografii kurdyjskiej. Mimo późnego startu i wielu trudności Kurdowie dorobili się wszakże kilku reprezentantów, którzy potrafili swoją wizją trafić do szerszej publiczności. Najbardziej znanym spośród tych twór-

1 Wszystkie tłumaczenia wypowiedzi reżysera zostały wykonane z języka angielskiego i pochodzą od autora. 
ców jest irański Kurd Bahman Ghobadi. Choć irańskie kino swoją renomę na międzynarodowej scenie budowało już od wielu lat, dopiero Ghobadi podjął problem społeczności kurdyjskiej na tak szeroką skalę, czyniąc go głównym tematem pierwszych czterech nakręconych przez siebie filmów pełnometrażowych.

W celu pełnego ujęcia zagadnienia należy pokrótce przybliżyć sytuację narodu kurdyjskiego. Kurdów uważa się za największy na świecie naród bez własnego państwa. Podanie dokładnej liczby nie jest możliwe ze względu brak na spójnej i oficjalnej ewidencji ludności rozrzuconej na bardzo dużym obszarze, podzielonym głównie między cztery państwa (Irak, Iran, Syria, Turcja). W każdym z tych krajów są oni znaczącą mniejszością, stanowiącą od kilku do $20 \%$ populacji ${ }^{2}$. Pochodzenie i początki historii Kurdów nie zostały dotychczas dokładnie zbadane. Tereny obecnego Kurdystanu przez setki lat były miejscem zderzania się wielu silnych kultur - babilońskiej, asyryjskiej, ormiańskiej, hebrajskiej, tureckiej, perskiej czy arabskiej. Czynnikiem, który jedność kurdyjską umacniał, zarazem nie pozwalając na głębszą integrację wewnątrz narodu, były góry, które zajmują prawie cały teren nazywany Kurdystanem. Tworzyły one naturalne schronienie i kształtowały unikalny charakter kurdyjskiej nacji. Wielkie geopolityczne przemiany, jakie przyniósł XX wiek, otworzyły możliwości i rozbudziły nadzieje na utworzenie własnego państwa, szybko jednak zaprzepaszczone. Oszukani przez społeczność międzynarodową Kurdowie zostali przedzieleni granicami innych krajów. Kraje te były nowymi tworami i dla utrzymania integralności potrzebowały wewnątrzpaństwowej jedności, której nie sprzyjała obecność mniejszości narodowych. Tak rozpoczął się okres, który trwa do dziś i który cechują rozbicie kurdyjskiej społeczności oraz nieustanna walka z władzami państw o prawo do współistnienia. Trudne warunki polityczne i geograficzne mają niezaprzeczalny wpływ na kulturę, między innymi na omawianą w niniejszym artykule kinematografię.

2 Strona internetowa Central Intelligence Agency: https://www.cia.gov/library/publications/the-world-factbook/geos/tu.html, dostęp: 30.01.2014. 


\section{Kinematografia kurdyjska}

\subsection{Kinematografia w Kurdystanie od swoich początków do przełomu wieków}

Pierwszy pokaz filmowy na terenie Kurdystanu odbył się w 1925 r. w Sulejmaniji. Za pierwszy produkt kinematografii kurdyjskiej uważany jest zaś niemy film pod tytułem Zare z roku 1926. Nazywanie go kurdyjskim jest jednak pewnym przekłamaniem, gdyż został on zrealizowany w Armenii przez armeńskiego reżysera Hamo Beknazariana. Film ów był po części finansowany ze środków kurdyjskich, ponadto opowiada on w pewnym fragmencie o historii Kurdów, prezentuje kurdyjskie zwyczaje i kulturę. Na przestrzeni XX w. (w latach 1932, 1959, 1979 i 1982) w Armenii wyprodukowano jeszcze kilka etnograficznych filmów dokumentalnych o Kurdach. Mimo tych epizodów należy jednak podkreślić, że kino kurdyjskie przez kolejne lata praktycznie nie istniało, zmagając się z trudnościami wynikłymi z warunków materialnych i politycznych. Sytuacja była trudna zarówno dla filmowców, jak i odbiorców kina. Rozproszenie na terenach różnych krajów skutkowało zróżnicowaną sytuacją dla potencjalnych twórców filmowych.

W Iraku w latach 70. pojawiła się grupa wykwalifikowanej kadry filmowej, zatrudnianej wszakże do projektów arabskich. W irackim Kurdystanie można było jednak obejrzeć filmy (głównie irańskie) z kurdyjskimi napisami. W Iranie rozwój kinematografii zdusiła w zarodku Rewolucja Islamska i związany z nią wzrost cenzury, ścisła kontrola twórców oraz scentralizowanie produkcji filmowej i telewizyjnej w Teheranie. W Turcji sytuacja była jeszcze trudniejsza, ze względu na prawnie usankcjonowany zakaz publicznego używania języka kurdyjskiego i wspominania o narodzie kurdyjskim. Bardzo znany reżyser kurdyjskiego pochodzenia Yılmaz Güney, zapytany o to, dlaczego nie tworzy w języku kurdyjskim, odpowiedział wprost, że język kurdyjski jest w Turcji zakazany. Güney nigdy otwarcie nie wspominał o Kurdach, jednak nietrudno w jego filmach doszukać się aluzji do spraw tego narodu - w ostatnim przed śmiercią wywiadzie ${ }^{3}$, udzielonym w 1984 r. francuskiemu dziennikarzowi Chrisowi Kutcherze ${ }^{4}$, twórca wyjaśniał, że gdyby użył w filmie języka kurdyjskie-

3 Wywiad po raz pierwszy ukazał się w czasopiśmie The Middle East Magazine w styczniu 1983 roku (Kutchera 1983).

4 Chris Kutchera - francuski dziennikarz, specjalista od Bliskiego Wschodu i Kurdów, publikował między innymi w Le Monde Diplomatique, wydał kilka książek o narodzie kurdyjskim. 
go, wszyscy aktorzy poszliby do więzienia. Przyznaje też, że jednym ze sposobów budowania skojarzeń z Kurdami było uzupełnianie scen kurdyjską muzyką instrumentalną. Jego najsłynniejsze dzieło, nagrodzona prestiżową Złotą Palmą na Festiwalu Filmowym w Cannes w roku 1982 Droga, było w Turcji zakazane do roku 1993. Sam Güney, w wyniku podejmowania w Turcji tematu Kurdów zmagał się z nietypowymi dla reżysera filmowego problemami - realizację niektórych ze swoich filmów nadzorował zza krat więziennych.

Zmiany przyszły na przełomie lat 80 . i 90 . - rozwój sposobów dystrybucji filmowej, a dokładnie pojawienie się kaset wideo oraz anten satelitarnych, znacznie ułatwił rozprzestrzenianie się filmów na terenach Kurdystanu, zaś władzom poszczególnych państw utrudnił kontrolę zjawiska. W 1989 r. w Iraku podjęto próbę nagrania pierwszego kurdyjskiego filmu fabularnego, jednak produkcja była ściśle kontrolowana przez rząd iracki. Scenariusz został napisany po arabsku i dopiero potem przetłumaczony na język kurdyjski. Przedsięwzięcie zostało przerwane ze względu na pierwszą wojnę w Zatoce. Następujące $\mathrm{w}$ kolejnych latach zmiany polityczne pozwoliły na utworzenie Kurdyjskiego Rządu Narodowego w ramach Autonomicznego Regionu Kurdystanu Irackiego. Działające przy nim ministerstwo kultury wspierało rozwój czy, de facto, utworzenie od zera kurdyjskiej kinematografii. Jednak to $\mathrm{w}$ Turcji, na początku lat dziewięćdziesiątych, powstał pierwszy popularny wśród Kurdów i przez nich stworzony film - był to Mem i Zin tureckiego reżysera Ümita Elçi. Film jest oparty na ludowym kurdyjskim podaniu, którego najpopularniejsza dziś wersja została spisana w XVII w. przez jednego z najbardziej znanych pisarzy w historii kurdyjskiej - Ahmada Khani. Kasety wideo z tym filmem dotarły do szerszej publiczności i zachęciły Kurdów do spróbowania swoich sił w tworzeniu dzieł filmowych.

Mustafa Gündoğdu, dyrektor i twórca Kurdyjskiego Centrum Kulturalnego w Londynie, wylicza trzy przyczyny, które w latach dziewięćdziesiątych zadecydowały o tym, że możemy dziś mówić o kinie kurdyjskim $^{5}$. Pierwsza to warsztaty filmowe zorganizowane przez Kurdyjskie Centrum Kulturalne w 1995 r. Przeprowadzone przez dwójkę asystentów Yılmaza Güneya okazały się dużym sukcesem, ponieważ kilku z uczestników tych warsztatów zostało później zawodowymi filmowcami, którzy zdobyli uznanie na scenie międzynarodowej. Kolejna rzecz to rejestracja przez Halila Uysala, który zmienił

5 Gündoğdu, Mustafa. An introduction to Kurdish Cinema, http://www.academia.edu/3480970/An_Introduction_to_Kurdish_Cinema, dostęp: 17.01.2014. 
nazwisko na Dağ (tur. 'góra'), życia górskich partyzantów. Dağ po powrocie z Europy dołączył do partyzantki i nakręcił kilka filmów na ten temat, co pozwoliło odkryć dla kinematografii ów nieznany wcześniej świat. Trzecia z wymienionych przez Gündoğdu spraw to rozwój kina $\mathrm{w}$ diasporze, co pozwoliło walczyć $\mathrm{z}$ rozpowszechnionym na Zachodzie stereotypem Kurda jako wiecznego partyzanta. Sto lat po wynalezieniu kinematografu Kurdowie otrzymali swoją szansę i zachłysnęli się kinem. Naród bez państwa użył nowego dla siebie medium przede wszystkim do opowiedzenia światu o sobie. Zdecydowana większość z powstających wtedy filmów podejmuje temat zmagania się narodu z licznymi przeciwnościami, jakie postawiła przed Kurdami sytuacja polityczno-społeczna oraz ukazuje unikalną kulturę, którą mogą się poszczycić. Nie ulega bowiem wątpliwości, że naród ten ma własną kulturę, którą z łatwością można oddzielić i odróżnić od pozostałych, niezwykle silnych i wpływowych kultur $\mathrm{w}$ regionie. Kurdowie na przestrzeni wielu lat, opierając się wpływom sąsiadów, wytworzyli własne wzorce i na trwałe zapisali się na kartach historii Bliskiego Wschodu. Swoją tożsamość kulturową wyrażają zarówno w muzyce, m.in. Kayhan Kalhor, Aram Tigran, Şivan Perwer, literaturze, np. Ahmad Khani, Ali Hariri, jak i zwyczajach czy tradycjach. W końcu przyszła też pora na nowoczesne formy twórczości, do których należy kino (Kreyenbrock 1996: 79-81).

\subsection{Bahman Ghobadi}

Postacią, która poprowadziła kinematografię kurdyjską od przejściowego okresu lat dziewięćdziesiątych do bardziej dojrzałej fazy, jest Bahman Ghobadi. Swoim pierwszym pełnometrażowym dziełem Czas pijanych koni zdobył on w 2000 r. na Festiwalu Filmowym w Cannes Złotą Kamerę - nagrodę dla najlepszych filmów debiutujących w pełnym metrażu reżyserów.

Ghobadi urodził się w 1969 r. w Baneh w ostanie Kurdystan w Iranie, co jest bardzo ważne dla jego całej twórczości. Miejsce to znajduje się niedaleko granicy z Irakiem, która była i jest terenem dramatycznych wydarzeń oraz zjawisk tworzących kurdyjską historię, takich jak wojna irańsko-iracka (1980-1988) czy przemyt alkoholu przez niedostępne góry. Ghobadi ukończył studia artystyczne w Teheranie i zajął się najpierw fotografią, a później krótkimi formami filmowymi. Jego kariera nabrała rozpędu w momencie, gdy został asystentem jednego $\mathrm{z}$ najsłynniejszych irańskich reżyserów filmowych - Abbasa Kiarostamiego przy produkcji Poniesie nas wiatr 
z 1999 r. W kolejnym roku uczestniczył w tworzeniu filmu Tablice Samiry Makhmalbaf, przy którym asystował jej ojciec, znany reżyser Mohsen Makhmalbaf, zaś Ghobadi dostał jedną z dwóch głównych ról. Kolejnym krokiem była już samodzielna kariera reżysera filmowego. Tablice są dziełem, które również za pomocą metaforycznych obrazów ukazuje los Kurdów, warto jednak skupić się na początkowej, pełnometrażowej filmografii Ghobadiego, która obejmuie wcześniej wspomniany Czas pijanych koni, Zagubionych w Iraku ${ }^{6}$, Gdyby żótwie mogły latać oraz Pótksiężyc. Wybór filmów jest nieprzypadkowy, łączy je zbliżona tematyka i bohaterowie. Upraszczając, można by rzec, że bohaterem wszystkich tych dzieł jest naród kurdyjski oraz jego walka o przetrwanie, prawo do samostanowienia i własnej kulturowej tożsamości.

Warto poświęcić kilka słów metodom pracy reżysera, gdyż odzwierciedlają one warunki, w jakich tworzy oraz mają wpływ na jego styl. Ze względu na scharakteryzowaną wyżej kondycję kina w Kurdystanie niemożliwe było znalezienie do każdego z filmów profesjonalnych aktorów, dlatego większość odtwórców ról w filmach Bahmana Ghobadiego to amatorzy, niemający wcześniej styczności z tworzeniem kina. Obrazuje to anegdota, którą opowiedział reżyser w wywiadzie dla New York Timesa (Scarlet 2007). Gdy jeden z aktorów - Allah-Morad Rashtian ${ }^{7}$, grający rolę Audeh w Zagubionych w Iraku oraz Kako w Pótksiężycu - skończył swój pierwszy dzień na planie, podziękował Ghobadiemu za współpracę i pożegnał się z ekipą filmową. Reżyser zasugerował mu, że widzą się jutro, co wywołało zdziwienie aktora, gdyż zdjęcia trwały około dziesięciu godzin, przez co aktor był przekonany, iż materiału na dwugodzinny film jest aż nadto. Reżyser musiał powołać się na wiele autorytetów, aby aktor uwierzył mu, że okres zdjęciowy potrwa miesiąc . Znając tę anegdotę oraz postacie, w które wcielił się Rashtian, nietrudno ulec wrażeniu, że ten nie tyle gra, co jest po prostu sobą. W miarę rozwoju kariery, mimo opierania obsady na aktorach amatorskich, zdarzało się też Ghobaldiemu współpracować ze znanymi postaciami, takimi jak Golshifteh Farahani, która zagrała w Pótksiężycu, gdy miała na koncie już klika filmów. Kolejną rzeczą charakterystyczną dla twórczości Ghobadiego jest budowanie fabuły filmów na własnych do-

6 Tłumaczenie własne z języka perskiego - film nie ma oficjalnego polskiego tytułu ze względu na brak dystrybucji w naszym kraju.

7 Wszystkie informacje dotyczące obsady filmów oraz autorstwa muzyki pochodzą z oficjalnej strony internetowej Mij Film, wytwórni Bahmana Ghobadiego: http://www.mijfilm.com/filmography/turtles-can-fly ${ }_{2}$ dostęp: 28.08.2014. 
świadczeniach. W przypadku debiutanckiego Czasu pijanych koni postanowił on nagrać osiem krótkich epizodów, które dopiero w trakcie pracy nad filmem udało się połączyć w całość. Ze względu na miejsce dorastania Bahman Ghobadi przesiąkł najróżniejszymi historiami, które teraz w swojej twórczości przedstawia widzowi.

\subsection{Twórczość i działalność Ghobadiego a tożsamość narodowa Kurdów}

W okresie po produkcji pełnometrażowego debiutu Bahman Ghobadi ujawnił, że jego marzeniem jest stworzenie „prawdziwie kurdyjskiego kina" (Kutchera 2003). Samo użycie pojęcia kino może być źródłem wątpliwości, czy chodzi o pojedyncze dzieła, czy o szerszy kontekst, instytucjonalną kinematografię. Wątpliwości te reżyser jednak rozwiewa dość zdecydowanie:

Kurdyjskie kino jest jak ciężarna kobieta. Ktoś musi jej pomóc urodzić. Nie wolno pozwolić jej umrzeć. Nie jesteście w stanie wyobrazić sobie, jak się czuję. Są tylko cztery czy pięć sal kinowych w irańskim Kurdystanie. A ja chcę być na równej stopie z najlepszymi na świecie (Kutchera 2003).

Życiową misją Ghobadiego jest stworzenie Kurdom warunków zbliżonych do tych, jakie mają zarówno twórcy, jak i odbiorcy w krajach o rozwiniętej kulturze filmowej. Reżyser zaraził swoich rodaków kinem już po stworzeniu Czasu pijanych koni:

Gdy idę ulicą, ludzie podchodzą do mnie - starzy i młodzi - ze scenariuszami. Ludzie kupują kamery. Ludzie modlą się, aby ich dzieci zostały filmowcami (Sciolino 2000).

Z dzisiejszej perspektywy możemy zauważyć, że nie była to tylko chwilowa moda i Ghobadi wychował nowe pokolenie kurdyjskich filmowców, które kontynuuje pracę nad rejestrowaniem kurdyjskiej rzeczywistości za pomocą kamery filmowej. Przykładem może być Soran Ebrahim, który u Ghobadiego pierwszy raz wystąpił na ekranie. Odtwórca roli młodego chłopca o pseudonimie Sattelite w Gdyby żótwie mogły latać w 2011 r. zagrał główną rolę w filmie opowiadającym o trudnej miłości dwojga młodych ludzi pod tytułem Czerwone serce $e^{8}$ i planuje on w dłuższej perspektywie

8 Tłumaczenie własne z języka norweskiego - brak dystrybucji w Polsce. 
tworzenie swoich własnych dzieł. Ponadto Bahman Ghobadi założył, także w przełomowym dla niego 2000 r., wytwórnię Mij Film. Na stronie projektu czytamy:

Od momentu założenia, Mij jest oddane wspieraniu ambitnego kurdyjskiego kina. (...) Mij Film produkuje rocznie dwa do trzech pełnometrażowych filmów oraz krótkometrażowe produkcje poświęcone tematom etnicznym w nadziei, że ich głos znajdzie przestrzeń, w której będzie usłyszany i zrozumiany 9 .

Reżyser zarówno w twórczości filmowej, jak i w innej działalności poświęcił się nadaniu nowoczesnego wymiaru kurdyjskiej oralnej tradycji opowiadania historii. Tradycji, która była podstawą podtrzymywania unikalnej tożsamości, środkiem przechowywania mitologii, historii narodowej i zwyczajów. Wzmocnił również siłę głosu mówiącego o Kurdach na świecie, świadom przekłamań na ich temat $\mathrm{w}$ przekazach medialnych przy jednoczesnym braku udziału Kurdów w globalnej kulturze:

Jest sporo nieporozumień na temat Kurdów. Są widziani zawsze jako ludzie noszący karabiny i strzelający do innych ludzi. Zawsze, gdy wybieram się do Kurdystanu, słyszę: „Uważaj, mogą Ci odciąć głowę"10.

Po wprowadzeniu dotyczącym kina kurdyjskiego, osoby reżysera i jego pracy na rzecz budowania kurdyjskiej tożsamości narodowej, w dalszej części przedstawione zostaną poszczególne motywy łączące wymienione wcześniej dzieła, które przedstawiają odbiorcy tych dzieł spójny obraz Kurda, jego otoczenia i sytuacji społeczno-politycznej, w której się znajduje. Najpierw jednak należy krótko streścić fabułę omawianych filmów w celu ułatwienia zrozumienia tekstu osobom, które $\mathrm{z}$ danym materiałem filmowym nie miały do czynienia.

${ }^{9}$ Oficjalna strona internetowa Mij Film: http://www.mijfilm.com/about-mij-film, dostęp: 28.08.2014.

${ }^{10}$ Tamże. 


\section{Omówienie treści filmów Bahmana Ghobadiego}

\subsection{Streszczenia fabuł filmów}

Czas pijanych koni - historia osieroconego chłopca, który zostaje głową rodziny i przez trudną sytuację jest zmuszony do ciężkiej pracy jako przemytnik, aby utrzymać rodzeństwo i zarobić na operację upośledzonego brata.

Zagubieni $w$ Iraku - fabuła opowiada o starym kurdyjskim muzyku, który dowiadując się, że jego żona postanowiła uciec z jego najlepszym przyjacielem, postanawia wraz ze swoimi dwoma synami wyruszyć w drogę i odnaleźć małżonkę. Akcja filmu rozgrywa się podczas konfliktu irańsko-irackiego w latach osiemdziesiątych.

Gdyby żótwie mogły latać - akcja rozgrywa się w obozie uchodźców na pograniczu turecko-irackim w przeddzień inwazji Amerykanów na Irak, głównymi bohaterami są dzieci, z których wiele pracuje przy rozbrajaniu min. Jedno $\mathrm{z}$ nich, chłopiec o pseudonimie Sattelite, zna język angielski, co decyduje o szczególnej pozycji zajmowanej przezeń w tej specyficznej społeczności

Pótksiężyc - w tym filmie reżyser opowiada historię słynnego kurdyjskiego muzyka o imieniu Mamo, mieszkającego na terenie Iranu. Po wyzwoleniu Iraku spod władzy Saddama Husseina i otrzymaniu pozwolenia na wjazd do Iraku bohater wybiera się wraz ze swoimi licznymi synami do irackiego Kurdystanu, aby dać tam koncert.

\subsection{Poszczególne motywy w omawianych dziełach filmowych}

\subsubsection{Granice}

W każdym z wymienionych filmów fabuła zbudowana jest wokół granic. Mówi o tym sam reżyser w cytowanym już wywiadzie dla New York Timesa:

Nauczyłem się znaczenia granicy $\mathrm{w}$ dzieciństwie. Jestem dobrze zaznajomiony z zapachem granicy. 40 milionów Kurdów jest rozbitych pomiędzy cztery czy pięć państw, niektórzy są nawet w Rosji i Europie, i oni wszyscy mają między sobą granice. Wielu członków mojej rodziny mieszka w Kurdystanie irackim i muszę czekać miesiące czy nawet rok, zanim otrzymam pozwolenie i będę mógł ich odwiedzić (Scarlet 2007). 
Granice są tym, co definiuje naród kurdyjski od wielu lat, to one zmuszają Kurdów do przemytu (Czas pijanych koni), są czynnikiem utrudniającym podróże i umożliwiającym nacjom okupantów represje (Pótksiężyc). Bohaterowie Pótksiężyca są zmuszeni do przekraczania granicy irańsko-irackiej, jednak czekanie na pozwolenie trwa siedem miesięcy. Kobieta (wokalistka) takiego pozwolenia nie otrzymuje, Mamo i synowie podejmują nieudaną próbę przewiezienia jej mimo to. Na granicy ich autobus zostaje brutalnie przeszukany. Różne prawa państw, w których Kurdowie mieszkają, sprawiają, że przekraczanie granicy staje się trudne. Zwykle jest to granica irańsko-iracka, jednak w Gdyby żótwie mogły latać fabuła osadzona jest w obozie uchodźców na pograniczu iracko-tureckim. Tak żywa obecność granic w filmach Ghobadiego pokazuje, jak duży wpływ na jego twórczość mają własne doświadczenia reżysera - dzieciństwo w irańskim Kurdystanie pozwoliło mu dokładnie przyjrzeć się sytuacji, którą potem przedstawiał w filmach. Jak powiedział w maju 2007 r. Peterowi Scarletowi, dyrektorowi artystycznemu Tribeca Film Festival ${ }^{11}$, 70\% scenariusza Czas pijanych koni pochodziło od mieszkańców wioski, w której film był kręcony, z ich doświadczeń i przeżyć.

Granica z definicji jest czynnikiem dzielącym, nie zaś łączącym. Należy zaznaczyć, że mimo iż Kurdowie nigdy nie posiadali własnego państwa, to przed wiekiem XX cieszyli się względną wolnością, gdyż granice imperiów nie były tak pilnie strzeżone jak od momentu podziału świata uwarunkowanego dwoma wojnami światowymi i traktatami międzynarodowymi. To właśnie granice nie pozwalają Kurdom na pełną, wewnętrzną integrację. Cała droga bohaterów Pótksię$\dot{z}$ yca ma za cel przekroczenie granicy, notorycznie utrudniane przez władze. W ostatnich scenach Czasu pijanych koni i Zagubionych w Ira$k u$ główni bohaterowie przekraczają nielegalnie granice, co podkreśla znaczenie tego procederu w życiu Kurdów. Granica ukazana w filmach jako granica fizyczna, którą trzeba przekraczać, ma symbolizować podział narodu kurdyjskiego.

\subsubsection{Muzyka}

Muzyka w filmach Bahmana Ghobadiego odgrywa bardzo ważną rolę, a w Pótksiężycu zajmuje wręcz centralne miejsce. Sam reżyser twierdzi, że gdyby nie został reżyserem filmowym, to prawdopodob-

11 Por.: wywiad wideo Petera Scarleta $\mathrm{z}$ Bahmanem Ghobadim: http://www.youtube.com/watch ?v=9mTQrvPNvXc, dostęp: 17.01.2014. 
nie byłby muzykiem, co tłumaczy rolę, jaką w swoich filmach przyznaje on muzyce i muzykom. Według Fuada Jommy muzyka, w przeciwieństwie do innych gałęzi kultury, jednoczy wszystkich Kurdów (Jomma 2001: 103). Można się tu odwołać do kolejnej wypowiedzi reżysera:

[...] nauczyliśmy się być optymistyczni co do przyszłości. Dlatego staramy się cieszyć życiem i słuchać muzyki. Możemy nie jeść przez tydzień, ale koniecznie musimy mieć w pobliżu swoje kasety z muzyką lub kogoś, kto chwyci za coś do wybijania rytmu, kto inny zaczyna śpiewać i wszyscy łapiemy za chusty do tańca.

Pótksiężyc jest swoistym hołdem dla muzyki, jej zasług w integracji narodu, mimo trudności, jakie nakładane są przez władze państw, w których Kurdowie się znajdują. Możemy w nim zobaczyć tradycyjne instrumenty, miejsce, gdzie zostają one wytworzone, próby muzyków czy wioskę, gdzie zesłane zostały kobiety, którym zakazano śpiewać. Ta ostatnia sytuacja wynika z prawa obowiązującego w Iranie (rzecz dzieje się w irańskiej części Kurdystanu), gdzie po Rewolucji Islamskiej w 1979 r. kobietom zakazano publicznego śpiewania w innej sytuacji niż jako chór. W wiosce tej Mamo i jego synowie znajdują się, by zabrać ze sobą wokalistkę, bez której Mamo nie chce odbyć swojego koncertu. Kobieta jednak nie ma pozwolenia na wyjazd do Iraku, co więcej, zaniedbała swój głos, paląc papierosy. Władze irańskie za wszelką cenę próbują udaremnić wyjazd wokalistki z Iranu. Cała ta sytuacja pokazuje, jak Kurdowie są nieustannie rozdzielani pomimo stanowienia swoistej jedności.

Mimo nieuniknionych wpływów zachodnich, najważniejsze miejsce w życiu Kurdów zajmuje muzyka tradycyjna. Szacunek, jakim się cieszy wśród Kurdów, możemy zaobserwować w reakcjach napotkanych ludzi na osobę Mamo. W filmach Bahmana Ghobadiego widzimy szerokie spektrum instrumentów: zarówno tych charakterystycznych dla całego regionu Bliskiego i Środkowego Wschodu, jak i typowo kurdyjskich. Brzmienie tych instrumentów jest zwykle szorstkie i ostre, dla nieprzystosowanego do takich dźwięków słuchacza wywodzącego się z kultury zachodniej być może nawet nieprzyjemne. Wśród typowo kurdyjskich można wymienić flet zerne ${ }^{12}$ obecny w scenie z Zagubionych $w$ Iraku, w której synowie głównego bohatera spontanicznie inicjują na weselu utwór, zaś zebrani dookoła natychmiast zaczynają tańczyć. W scenie tej możemy zobaczyć tradycyjny

\footnotetext{
${ }^{12}$ Można również spotkać się z pisownią zirne.
} 
kurdyjski taniec - debkę. Taniec jest kolejnym elementem kultury Kurdów, w którym potrafili oni znaleźć swój własny język. Według Ghobadiego to właśnie taniec wraz z muzyką jest odpowiedzią Kurdów na trudne warunki, w których przyszło im żyć. Częstą sytuacją jest śpiew w momencie np. jazdy samochodem, umilający czas spędzany w aucie. Możemy to obserwować choćby na początku Czasu pijanych koni.

Należy jeszcze powiedzieć o ścieżce dźwiękowej, która doskonale oddaje klimat surowych gór Zagros. Autorem muzyki do trzech (poza Zagubionymi $w$ Iraku, do których ścieżkę dźwiękową stworzył Arsalan Kamkar) z czterech filmów jest Hossein Alizadeh, Irańczyk urodzony w Teheranie i z pochodzenia niemający z Kurdystanem nic wspólnego. Alizadeh jest jednak jednym $\mathrm{z}$ wybitniejszych przedstawicieli irańskiej klasycznej sceny muzycznej, z dużym profesjonalizmem i talentem podszedł on do zadania, przerabiając kurdyjskie motywy na spójną ilustrację dźwiękową.

\subsubsection{Dzieci}

W Gdyby żótwie mogły latać oraz w Czasie pijanych koni reżyser wiele uwagi poświęca dzieciom. Ich sytuacja jest diametralnie różna od sytuacji dzieci w krajach rozwiniętych, a nawet krajach, na których terenie Kurdystan leży, takich jak Turcja czy Iran. Dostęp do edukacji jest często istotnie ograniczony, chociażby przez surowe warunki geograficzne, które utrudniają przemieszczanie się. W Czasie pijanych koni obserwujemy scenę w szkolnej klasie, gdzie dzieci są wyraźnie zróżnicowane pod względem wieku, zaś w sali, mimo panującej dookoła zimy, nie ma ogrzewania. Warto jednak zaznaczyć, że chłopcy uczą się razem z dziewczynkami. Warunki nauki są przedstawione również w Pótksiężycu, gdzie widzimy grupę dzieci nauczanych na świeżym powietrzu, na szczycie wzniesienia, przy wietrznej pogodzie. Lekcje odbywają się tam dlatego, że wioska została zalana z powodu pęknięcia tamy. Obraz ten pokazuje nam, że dorośli mimo licznych przeszkód starają się zapewnić dzieciom choćby podstawową wiedzę. Często jednak nawet ta podstawowa edukacja porzucana jest na rzecz pracy zarobkowej.

Dzieci są zmuszane do pracy od najwcześniejszych lat. Sceny z pracującymi kilku- czy kilkunastolatkami są bardzo częste w Czasie pijanych koni oraz Gdyby żótwie mogły latać. W przypadku pierwszego z tych filmów dzieci parają się przemytem. Główny bohater, Ayoub musi zarobić pieniądze na operację swojego młodszego, upośledzo- 
nego brata. W pierwszej scenie filmu widzimy walkę toczącą się wśród dzieci o to, które zostanie przez dorosłych wybrane do pracy. $\mathrm{Na}$ ironię zakrawa fakt, iż jako przykrywkę dla przemytu nadzorujący grupę wybiera książki z ćwiczeniami, które dzieci powinny wypełniać w szkole. W przypadku Gdyby żótwie mogły latać dzieci wykorzystywane są do prac niezwykle niebezpiecznych - rozbrajania min, selekcji łusek po pociskach. Jeden z pracujących chłopców o imieniu Hengov jest pozbawiony rąk, reżyser nie rozstrzyga jednak kwestii, czy ręce stracił przy takiej właśnie niebezpiecznej pracy. Oprócz trudnej sytuacji materialnej przed posyłaniem dzieci do szkoły może powstrzymywać (w Turcji) brak języka kurdyjskiego w szkołach (Yıldız 2010: 68). Dziecko znające od urodzenia jedynie kurdyjski nie jest w stanie uczyć się w języku tureckim.

\subsubsection{Rodzina}

Kurdowie, jak większość tradycyjnych społeczności, wielką wagę przywiązują do najmniejszej społecznej komórki, jaką jest rodzina. Słowo „najmniejsza” może być tu jednak mylące, ponieważ rodziny bywają nadzwyczaj liczna. Prawdopodobnie nie wynika to $\mathrm{z}$ wielożeństwa, ponieważ jest ono w Kurdystanie rzadkością (Jomma 2001: 110-111). Dużą rodziną poszczycić mógł się Mamo, którego podczas ostatniego koncertu miało wspomóc kilkunastu synów. Liczebność jego potomstwa zdaje się potwierdzać kurdyjską sentencję: „Dom, w którym jest złoto, może upaść. Nie zginie dom, w którym są synowie" (Jomma 2001: 107). Często funkcje całej rodziny pełnić musiały dzieci, jak Ayoub, pracujący na swoje rodzeństwo i jego siostra wychowująca młodszych braci. Mimo opieki sprawowanej nad resztą Ayoub nie ma prawa do decydowania o losie rodzeństwa - o małżeństwie własnej siostry zaaranżowanym przez wujka Ayoub dowiaduje się dopiero po fakcie. Rodzinę tworzy także tajemnicza para bohaterów w Gdyby żótwie mogły latać - bezręki Hengov i jego siostra Agrin, która opiekuje się małym chłopcem. Malec okazuje się synem Agrin, który przyszedł na świat w wyniku gwałtu, a młodziutka Agrin nie potrafi sobie z tym faktem poradzić. Jak widzimy, przytoczone przykłady nie przypominają tradycyjnego modelu rodziny znanego na Zachodzie. Losy wszystkich tych postaci wynikają jednak z warunków, w których przyszło im żyć. Trzeba pamiętać, że warunki ukazane $\mathrm{w}$ filmach przez reżysera, stanowią, zgodnie $\mathrm{z}$ wypowiedzią cytowaną $\mathrm{w}$ podrozdziale o jego metodach pracy, odzwierciedlenie prawdziwych, napotkanych przez niego sytuacji. Jak ważna dla sa- 
mego reżysera jest rodzina, można również zauważyć w działalności Mij Film - wspomnianej już wytwórni filmowej kierowanej przez Bahmana Ghobadiego, w ramach której w 2012 r. pełnometrażowy debiut w 2012 r. miała siostra Bahmana, Nahid. W tym roku, na festiwalu filmowym w Toronto ${ }^{13}$, premierę będzie miała kolejna rodzinna produkcja Mij Film, autorstwa Batina Ghobadiego - brata Bahmana. Wielką pomocą na początku filmowej kariery dla Bahmana Ghobadiego była jego matka, która w celu pozyskania środków na sfilmowanie Czasu pijanych koni sprzedała rodzinne meble ${ }^{14}$.

\subsubsection{Technologia i media}

Nowoczesna technologia w życiu Kurdów jest czymś nowym, społeczeństwo to jest oparte na bardzo tradycyjnych wartościach, dodatkowo społeczności przedstawiane w omawianych filmach to społeczności ubogie, dlatego dostęp do nowoczesnych technologii jest dla bohaterów Ghobadiego ograniczony, choć możliwy. W Pótksiężycu Mamo każe jednemu ze swoich synów wysyłać e-maile, aby poinformować o koncercie, z kolei do nawigacji używają oni map w komputerze, wszystko to dzięki mobilnemu Internetowi. Mapy pozwalają im zlokalizować się w przestrzeni oraz znaleźć drogę, ostatecznie okazują się jednak bezużyteczne $\mathrm{w}$ starciu $\mathrm{z}$ służbami granicznymi. Za główne źródło informacji służy radio (Czas pijanych koni), które jednak już w roku 2003, kiedy to dzieje się akcja Gdyby źótwie mogły latać, musi ustąpić miejsca telewizji i antenom satelitarnym. Sattelite zajmuje się instalowaniem takich anten, a dodatkowo, jako znający po trosze angielski, pomaga lokalnej starszyźnie zrozumieć newsy podawane $\mathrm{w}$ zagranicznych stacjach informacyjnych, dotyczące inwazji Stanów Zjednoczonych na Irak. Szukając kanału informacyjnego, trafia on na liczne kanały muzyczne, co wprawia w zakłopotanie starszyznę, która między sobą mówi o tym, że takie kanały są zakazane, uznając jednak, że zdobycie wiadomości o wojnie jest istotniejsze i ostatecznie przymykając na to oko. Sattelite, nie wiemy, czy ze względu na opaczne zrozumienie, czy też celowe wprowadzanie dorosłych w błąd, oznajmia, że na amerykańskim kanale informacyjnym podawana jest prognoza pogody, podczas gdy na ekranie wi-

${ }^{13}$ Strona internetowa Toronto International Film Festival, http://www.tiff.net/festivals/thefestival/programmes/discovery/mardan, dostęp: 28.08.2014.

${ }^{14}$ Informacja uzyskana podczas prywatnego spotkania z reżyserem w Krakowie, dnia 13.05.2014. 
dzimy prezydenta Busha. Brak podstawowego wykształcenia wpływa na niemożność zrozumienia wiadomości innego pochodzenia niż własne i lokalne, na skutek barier językowych oraz kulturowych.

\subsubsection{Polityka i wiedza o świecie}

O wpływie polityki była wcześniej mowa we fragmencie poświęconym granicom. Wiemy już, jak polityczne decyzje, podjęte bez udziału samych Kurdów, odmieniły ich życia. W scenie z Gdyby żótwie mogły latać Sattelite dyskutuje ze starszym mężczyzną na temat rodzin w wiosce. Okazuje się, że niezgoda co do ich liczby wynika z faktu, iż starszy mężczyzna dzieli wioskę na część po stronie irackiej i część po stronie tureckiej. Jak widać, odkreślane od linijki granice dzieliły nawet pojedyncze wioski.

Poznajemy też wpływ Saddama Husseina na życie Kurdów w Zagubionych $w$ Iraku trójka głównych bohaterów trafia do zrujnowanej wioski. Okazuje się, że została ona zniszczona, według ostatnich jej mieszkańców, na rozkaz Saddama. Mówią oni również, że nie opuszczą tego miejsca, nawet gdyby przywódca Iraku zjawił się w wiosce we własnej osobie, co pokazuje ich przywiązanie do ziemi.

Nawiązując do tego, co napisałem w podrozdziale „Technologia i media", można jeszcze nadmienić, że Sattelite, widząc prezydenta George'a Busha, mówi, że świat jest w jego rękach. Przekaz medialny zdominowany przez proamerykańsko nastawione media, $\mathrm{w}$ połączeniu $\mathrm{z}$ selektywnym odbiorem ze względu na braki w edukacji, bardzo mocno wpływa na widzenie świata. Do kurdyjskich wiosek docierają jedynie skrawki kultury zachodniej, których to reprezentacją jest plakat przedstawiający kulturystę, przywieziony przez Ayouba bratu jako prezent. Wiedza bywa też niezbyt obszerna, jeśli chodzi o najbliższych sąsiadów. Kako, kierowca wiozący Mamo i jego synów, w Półksiężycu mówi, że po turecku zna tylko jedno zdanie - Seni seviyorum (pol. 'kocham cię'), jednak nie pamięta, co ono oznacza.

\subsubsection{Humor i rozrywka}

Poza omówioną już muzyką i tańcem, którym Kurdowie potrafią oddawać się godzinami i które pozwalają im na chwilę oddechu w często trudnym życiu, nieprzecenioną wartością jest dla tej społeczności poczucie humoru. Bahman Ghobadi opowiada, że zacho- 
wanie poczucia humoru jest koniecznością, stanowi reakcję na otaczający świat, gdzie wojna wygląda jak zabawa, a informacja o kolejnej masakrze zostaje skwitowana jedynie gorzkim uśmiechem. Jest to zrozumiała odpowiedź na pewien poziom okrucieństwa, który wydaje się już tylko i wyłącznie absurdalny. W filmach Bahmana Ghobadiego możemy odnaleźć wiele humorystycznych fragmentów, szczególnym przykładem są tu postacie Kako z Pótksiężyca oraz Satellite z Gdyby źótwie mogły latać. W jednej ze scen Półksiężyca Mamo przypadkiem odstrzelił jednemu ze swoich synów ucho, żartują oni później między sobą, że wygląda on po tym zdarzeniu jak Vincent van Gogh. Jeśli chodzi o rozrywki, w pierwszej scenie Półksiężyca oglądamy scenę walk kogutów, w której uczestniczą niezliczone rzesze mężczyzn. Obserwują oni poczynania dwóch walczących ze sobą ptaków, obstawiając wynik takiej walki, a oprawę muzyczną zapewnia zespół złożony z dzieci.

\section{Podsumowanie}

Przedstawiony powyżej ogólnie, na podstawie wybranych istotnych motywów, wizerunek Kurdów w filmach Bahmana Ghobadiego w wymiarze społeczno-politycznym jest ponury. Dominują obrazy biedy, trudnej sytuacji rodziny i dzieci czy trudności politycznych, wynikających z dokonanego bez udziału Kurdów podziału granic. Oglądamy naród zmagający się z codziennością, który jednak próbuje zachować godność i trwać przy swoich korzeniach, pielęgnując odrębność poprzez język i kulturę. Naród, który mimo trudnych sytuacji potrafi podejść do życia z dystansem. Co ważne, widzimy też w bohaterach filmów jednostki silne, stawiające czoła nieludzkim warunkom, w których przyszło im żyć. Filmy te nie prezentują pełnego obrazu, szczególnie w kontekście dzisiejszej sytuacji, w której Kurdystan iracki ze stolicą w Erbilu (który pojawia się raz w Gdyby żótwie mogły latać) rozwija się i wygląda zgoła inaczej niż przedstawiane $\mathrm{w}$ filmach wioski. Należy jednak pamiętać, że omawiane dzieła pochodzą z lat 2000-2006, a jednym z głównych celów przyświecających reżyserowi było opowiedzenie o Kurdach. Ghobadi wywiązuje się z postawionego sobie zadania bardzo sprawnie, korzystając z szerokiej gamy środków, jakimi dysponuje język filmowy. Odwołuje się zarówno do stylu dokumentalnego, jak i do narracji bliższej kinu artystycznemu, pamiętając także o historii kina kurdyjskiego, które dotychczas nie mówiło silnym głosem. Takim silnym głosem są niewątpliwie pierwsze cztery filmy pełnometrażowe przedstawiające wiele 
historii Kurdów. W jednej ze scen Zagubionych $w$ Iraku Bahman Ghobadi bezpośrednio nawiązuje do sceny ze swego pierwszego, o dwa lata wcześniejszego filmu, czyli Czasu pijanych koni, pokazując w ten sposób, że problemy, o których opowiadał, nie zostały dotychczas rozwiązane. W ostatnich dwóch pełnometrażowych filmach (Nikt nie rozumie perskich kotów, Sezon na nosorożca) reżyser odchodzi od tematyki kurdyjskiej. Możemy być jednak pewni, że w dalszej twórczości temat ten zostanie podjęty ponownie, poruszone wątki i motywy będą rozwijane, a postawione wcześniej pytania doczekają się choćby próby odpowiedzi.

\section{Bibliografia}

Dönmez-Colin, Gönül. 2008. Turkish Cinema: Identity, Distance and Belonging. Londyn: Reaktion Books Ltd.

Giedź, Maria. 2002. Węzeł kurdyjski. Warszawa: Dialog.

Jomma, Fuad. 2001. Kurdowie i Kurdystan. Gdańsk: Wydawnictwo L\&L i DJ.

Kreyenbrock, Phillip, Christine Allison. 1996. Kurdish Culture and Identity. Londyn: Zed Books Ltd.

Naficy, Hamid. 2001. An Accented Cinema: Exilic and Diasporic Filmmaking. New Jersey: Princeton University Press.

Yıldız, Kerim, Rachel Bernu, Julianne Stevenson. 2010. The Situation of Kurdish Children in Turkey. London: Kurdish Human Rights Project.

\section{Źródła internetowe}

Gündoğdu, Mustafa. An introduction to Kurdish Cinema, http://www.academia.edu/3480970/An_Introduction_to_Kurdish_ Cinema, dostęp: 17.01.2014.

Kutchera, Chris. 1983. Kurdistan Turkey: Yılmaz Güney's Last Film, The Middle East Magazine, http://www.chris-kutschera.com/A/Yilmaz\%20Guney.htm, dostęp: 17.04.2014.

Kutchera, Chris. 2003. Bahman Ghobadi and the Pain of Giving Birth to Kurdish Cinema, The Middle East Magazine, http://www.chris-kutschera.com/A/bahman_ghobadi.htm, dostęp: 21.10.2014. 
Oficjalna strona internetowa Mij Film [organizacji założonej przez Bahmana Ghobadiego i mającej na celu wspieranie kina w Kurdystanie], http://www.mijfilm.com, dostęp 28.08.2014.

Scarlet, Peter. 2007. Kurdish Director, Stuck between Iran and Iraq, New York Times,

http://www.nytimes.com/2007/12/16/movies/16scar.html?_r =1

\&, dostęp: 17.01.2014.

Sciolino, Eliane. 2000. Filming in Iran's Rugged Corner, Hoping

Prayer Works, New York Times,

http://www.nytimes.com/2000/10/26/movies/arts-abroad-

filming-in-iran-s-rugged-corner-hoping-prayer-

works.html? src = pm\&pagewanted = 1, dostęp: 26.10.2014.

Strona internetowa Central Intelligence Agency,

https://www.cia.gov/library/publications/the-world-

factbook/geos/tu.html, dostęp: 30.01.2014.

Strona internetowa Toronto International Film Festival, http://www.tiff.net/festivals/thefestival/programmes/discovery/ mardan, dostęp: 28.08.2014.

\section{Filmy}

Tablice (tyt. org. Takhte Siah), reż. Samira Makhmalbaf, 2000 r.

Czas pijanych koni (tyt. org. Demek jibo hespên serxweş), reż. B. Ghobadi, $2000 \mathrm{r}$.

Zagubieni w Iraku (tyt. org. Gomgaštegi dar Arâq), reż. B. Ghobadi, $2002 \mathrm{r}$.

Gdyby żótwie mogły latać (tyt. org. Kûsî Jî Dikarin Bifirin), reż. B. Ghobadi, $2004 \mathrm{r}$.

Pótksiężyc (tyt. org. Nîwe Mang), reż. B. Ghobadi, 2006 r.

\section{Abstract}

Kurdish Cinematography: The Image of Kurds in Bahman Ghobadi's Movies

Cinematography can be used as a weapon in the battle for identity. Kurdish people are in a constant need to reinvent their national identity. Some of them use cinema as a tool to tell their stories in order not to be forgotten. One of them - a critically acclaimed director from Iran, Bahman Ghobadi is known especially for his cinematic contribution to the Kurdish issue. The article briefly depicts the his- 
tory of Kurdish cinema and describes in detail the image of Kurds in Bahman Ghobadi's first four feature films - A Time for Drunken Horses (2000), Marooned in Iraq (2002), Turtles Can Fly (2004) and Halfmoon (2006). All these films are not only great pieces of art, full of symbolic images, but they also contain a complex image of the Kurdish nation. Ghobadi uses his camera to tell stories of small, local communities displaced between Iran, Iraq and Turkey, who struggle to maintain their own culture and dignity.

Keywords: Kurdish cinema, Kurdistan, Bahman Ghobadi, national identity 